\title{
JÓ SZÍNVONALÚ HAZAI TEJTERMELÓ ÜZEM GAZDASÁGI ELEMZÉSE
}

\author{
ôs \\ ECONOMIC ANALYSIS OF A GOOD QUALITY HUNGARIAN \\ DAIRY FARM WITH LEADING TECHNOLOGY \\ $-10$ \\ ${ }^{1}$ KovÁCS, Krisztián \\ ${ }^{1}$ VIDA, Viktória \\ ${ }^{2}$ MADAI, Hajnalka \\ ${ }^{1}$ SzÜCS, István \\ ?a
}

${ }^{1}$ Debreceni Egyetem, Gazdaságtudományi Kar, Gazdálkodástudományi Intézet, Üzemtani és Vállalati Tervezés nem önálló Tanszék (University of Debrecen, Faculty of Economics and Business, Institute of Applied Economics Sciences, Non-independent Department of Farm Business Management and Corporate Planning)

H-4032 Debrecen, Böszörményi út 138. e-mail: kovacs.krisztian@econ.unideb.hu

${ }^{2}$ Debreceni Egyetem, Gazdaságtudományi Kar, Gazdálkodástudományi Intézet, Vállalatgazdaságtani és Vállalkozásfejlesztés nem önálló Tanszék (University of Debrecen, Faculty of Economics and Business, Institute of Applied Economics Sciences, Non-independent Department of Business Economics and Business Development) H-4032 Debrecen, Böszörményi út 138

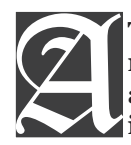

The research includes an economic analysis of the dairy farm based on farm data, which makes it possible to assess the cost-income ratio and partial efficiency of each sector, assuming that it operates at a good production level, and in the case of assumed greenfield investments, economy based on dynamic indicators (NPV, IRR, PI, DPP). As many domestic dairy farms produce with the most advanced technology available, and their indicators do not lag far behind the best farms in Western Europe, the so-called analyses refer to "good production standards or practices". The performed analysis is based on a deterministic simulation modelling created from a production plant's primary data which uses its own database. Some of the research findings are supported by data and calculations, while others are based on expert estimates and expert opinions. Based on our investigations, it can be stated that the so-called most important specific natural, economic, and investment analysis indicators of the model plant following good production practice in the case of milk production are the following: Specific annual milk yield 11,000 $\mathrm{kg} /$ year; Production value: 1,548.5 thousand HUF/cow; Production cost: 1,312 thousand HUF/cow; Net income: 236.5 thousand HUF/cow; EBITDA: 404.6 thousand HUF/cow; Discounted payback period without investment subsidy: 11 year; Discounted payback period at 50\% subsidy intensity: 6 years.

KuLCSSZAVAK: tejtermelés, Magyarország, jó színvonalú üzem, gazdasági elemzés

KEYWORDS: dairy farms, Hungary, leading technology, econoics analyse

JEL-KóDOK (JEL CODES): Q12, Q13

DOI: https://doi.org/10.3410o/TEJGAZDASAGvol78iss1-2pp43-64 


\section{BEVEZETÉS - INTRODUCTION}

2019-ben a mezőgazdasági ágazat (szolgáltatásokkal és másodlagos tevékenységekkel együtt) folyó alapáron számolt kibocsátási értéke mintegy 2,8 ezer milliárd forint volt, ebből 36\%-kal (1,o ezer milliárd forint) az állatok és az állati termékek részesedtek. Az állattenyésztés termelési értékének legnagyobb hányadát (36\%-át) a baromfi és a tojás adja, ezt követi a marha és a tej $29 \%$-os, a sertés $27 \%$-os, valamint az egyéb állatfaj és állati termék 8,1\%-os részesedéssel (KSH, 2020a).

Jelen tanulmány magában foglalja a tejtermelő üzemi adatokon alapuló - üzemgazdasági elemzését, mely által értékelhetővé válnak az egyes tejtermelő gazdaságok jó színvonalon való múködését feltételezve a költség-jövedelem viszonyok, illetve a müködési hatékonysága, valamint a feltételezett zöldmezős beruházások esetében a beruházás 10 éves időszakon értelemzett dinamikus mutatókon alapuló gazdaságossága.

Köztudomású, hogy a hazai tejtermelés az országos átlagadatok alapján elmarad a világ és Európa legfejlettebb üzemeihez, országaihoz viszonyítva a termelési színvonalat, a hatékonyságot és a versenyképességet illetően. Itt hívjuk fel azonban arra a tényre a figyelmet, hogy azért van néhány olyan hazai termelő üzem, amely a legfejlettebb technológiával termel, és mutatói érdemben nem maradnak el a legjobb nyugat-európai üzemekétől. Ebben a kutatásban az ún. „jó termelési színvonalra, illetve gyakorlatra" vonatkoznak az elemzések.

A kutatómunka fó célkitűzése a hazai tejtermelés jövedelemtermelő képességének, hatékonyságának és gazdaságosságának egzakt értékelése. A fő célkitüzés megvalósításához kapcsolódóan az alábbi specifikus célkitűzések megvalósítására, azaz kérdések megválaszolására törekedtünk:

1. Mi jellemzi a naturális ráfordításokat, a termelési költségeket, valamint ezek szerkezetét és összetételét?

2. Milyen kibocsátási szint, illetve paraméterek (hozam, értékesítési ár, termelési érték) jellemzik a termelést?

3. Hogyan alakul a gazdálkodás eredménye, a termelés hatékonysága (jövedelemtermelő képesség, jövedelmezőség, élő- munka-hatékonyság, tőkehatékonyság) rövidtávon, vagyis egy gazdálkodási évre vetítve?

4. Mi jellemzi az ágazati zöldmezős beruházások esetében a beruházás megtérülését (DPP), illetve gazdaságosságát (NPV, IRR, PI) 10 éves időszakot alapul véve?

5. Hogyan befolyásolják a termelés hatékonyságát és gazdaságosságát a gazdasági környezet egyes változásai, illetve az ezek révén a hozamokban, a minőségben, valamint az input- és output-árakban bekövetkező változások?

\section{A TEJTERMELÉS HELYZETE -} SitUATION OF THE DAIRY INDUSTRY

Uniós és hazai viszonylatban, a jövő minőségi élelmezése szempontjából elengedhetetlenül fontos a tejtermelés fejlesztése, hatékonyságának növelése. A középosztály vásárlóerejének növekedése mindenütt fokozza a tej, illetve tejtermékek iránti keresletet. Ugyanakkor gondot jelenet, hogy ez az ágazat felel az emberi tevékenységből fakadó üvegházhatású gázok kibocsátásának közel 4 százalékáért, ami globálisan körülbelül kétmilliárd tonna szén-dioxid-kibocsátásának felel meg. A globális metánkibocsátás mintegy 37\%-a szarvasmarhatartásból származik, ráadásul az ágazat fajlagosan nagyon sok földet és vizet használ a tej és a hús előállításáért. Ez az adat is jól alátámasztja a fenntarthatóság kérdését, melyet ČECHURA és KROUPOVÁ (2021) az Európai Unió vezetô tejgazdaságaiban végzett kutatási eredményei szerint is egyre fontosabb a tejtermelésben. Eredményei szerint az elemzett országok tejfeldolgozó ipara általában nem jellemezhető az erőforrások jelentős pazarlásával. A potenciális költségcsökkenést az országminták átlagának megfelelően 4-8\%-ra becsülik. Az általános technikai hatékonyság-csökkenések (OTE overall technical inefficiency) elsősorban rövid távú krízisek és ágazati struktúrából eredő hibák következményei. A meta-border becslések azonban bizonyos fokú rendszer-eredetû problémát is feltárnak, mint például a vezetői alkalmatlanság és az európai tejfeldolgozó ipar strukturális problémáit. 


\subsection{Nemzetgazdasági jelentőség piaci helyzet - National Economics and Market Outlook}

Magyarország uniós csatlakozásának az egyik legnagyobb kárvallottja a hazai tejhasznú szarvasmarha-ágazat volt. Az EU-csatlakozás után növekvő konkurenciával kellett számolni mind a nyerstej, mind a tejtermékek esetében. A feldolgozók nagy része külföldi tulajdonban volt, és nem volt előre kalkulálható a csatlakozás előtt, hogy a csatlakozással milyen változás következik be az alapanyag- vagy a késztermék-behozatal tekintetében (POPOVICS és TÓTH, 2006).

Azóta is, az elmúlt 15 évben az ágazatban komoly problémákkal kellett szembenézniük a termelőknek. A tejtermelés az EU-csatlakozás idején alakult kedvezőtlenül, majd 2006 után többé-kevésbé stabilizálódott az ágazat gazdasági helyzete. A 2014-ben kezdődő orosz embargó és a tejkvóta 2015-ös kivezetése ismét negatívan hatott az ágazat helyzetére.

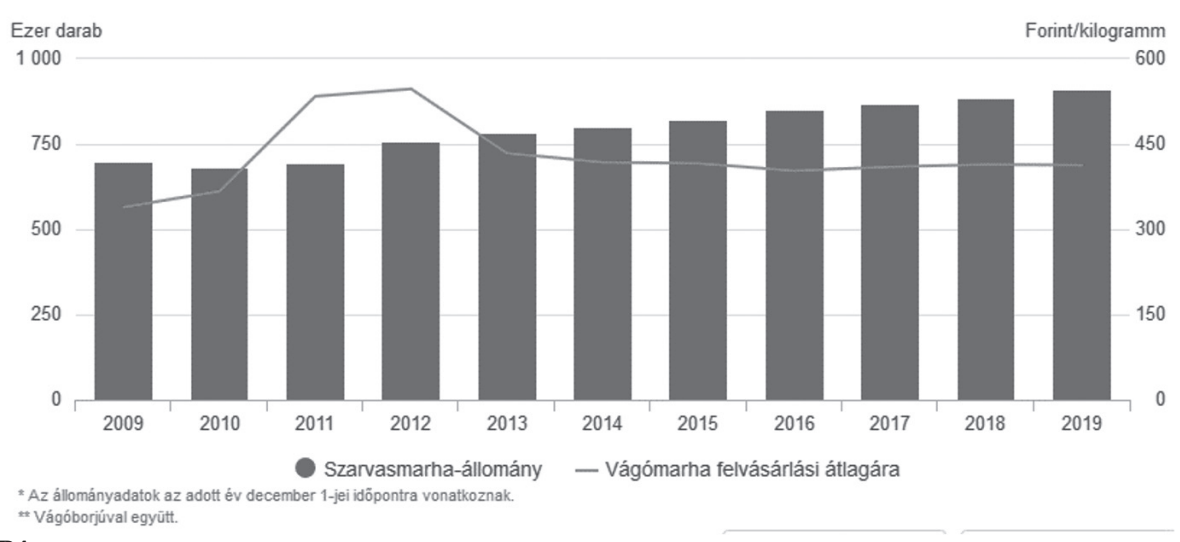

1. ÁBRA

A szarvasmarha-állomány és a vágómarha felvásárlási átlagárának alakulása (The Average Purchase Price of Cattle and Beef Cattle)

FIG. 1

Forrás (Source): KSH, 2020B

Megjegyzés (Note): ezer darab (thousand head); Forint/kilogramm (HUF/kilogram); szarvasmarha-állomány (cattle livestock); vágómarha felvásárlási ára (purchase price of cattle)

A hazai szarvasmarha-állomány 2019. december 1-jén 909,1 ezer volt. A tehénállomány (412 ezer) egy év alatt 2,2\%-kal nőtt, öt év alatt összességében 53 ezerrel gyarapodott, de ez elsősorban a húshasznú állománynak volt köszönhető. A húshasznú tehenek száma az elmúlt öt évben 65 ezerrel emelkedett, ami 63\%-os növekedésnek felelt meg. 2019-ben a felvásárolt vágómarhák száma 51 ezer volt, ami 4,9\%-kal csökkent az egy évvel korábbihoz képest, míg a fajlagos felvásárlási átlagár (413 Ft/kg élősúly) érdemben nem változott a 2018. évihez mérten (1. ábra). A hazai tehéntej felvásárlási ára 5,6\%-kal nőtt az egy évvel korábbihoz képest (2. ábra), így átlagosan $102 \mathrm{Ft} / \mathrm{kg}$ volt a tehéntej átlagos felvásárlási ára 2019ben (KSH, 202Oa).

Három és fél éve 91-110 Ft/kg között mozog a tej felvásárlási ára, ami ugyan EU-szinten alacsony, de komoly stabilitást jelent. A hazai tejtermelés 10-15 éves távlatban enyhén, de növekszik. 


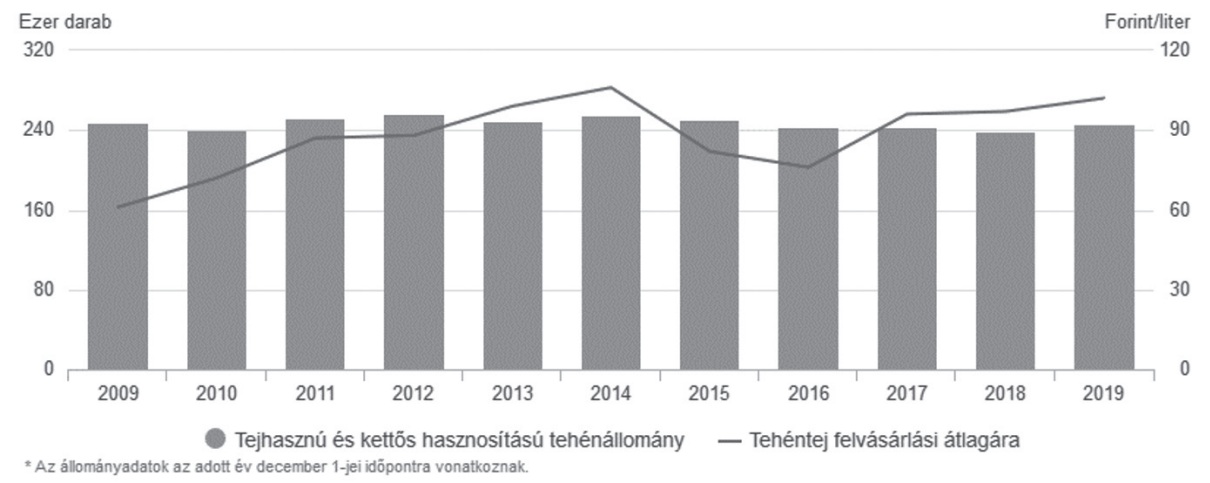

2. ÁBRA Az állományadatok az adott év december 1 -jei idôpontra vonatkoznak.

\section{A tejhasznú és a kettős hasznosítású tehénállomány valamint a tehéntej felvásárlási átlagárának alakulása (2009-2019)}

(The Average Purchase Price of Dairy and Dual-Use Cows and Cow's Milk (2009-2019))

Forrás (Source): KSH, 2020B

Megjegyzés (Note): ezer darab (thousand head); Forint/liter (HUF/litre); tejhasznú és kettős hasznosítású tehénállomány (milk and dual-use cow livestock); tehéntej felvásárlási ára (purchase price of cow’s milk)

A NAIK AKI PÁIR adatai szerint Magyarországon a nyerstej országos termelői átlagára 102,7 Ft/kg volt 2020. év szeptemberében. A nyerstej kiviteli ára 108,84 Ft/kg volt ugyanezen időszak alatt, az előző havihoz képest 12\%-kal nőtt, míg az előző év azonos hónapjához képest 3\%-kal csökkent. A kiviteli ár 6\%kal múlta felül a termelői átlagárat.

A hazai exportált magyar tej átlagára minden időszakban alatta maradt a legfőbb exportpiacunk Olaszország belföldi tejfelvásárlási árainak, de azt is elmondhatjuk, hogy három év átlagában gyakorlatilag a lengyel árakkal egyezett meg, jelentősen elmaradva a régió országainak árszínvonalától (3. ábra). A nyerstej átlagos zsírtartalma 3,6-3,9\% között, míg a fehérjetartalma 3,2-3,4\% között alakult az elmúlt 3 évben.

Az összes hazai szarvasmarha 47\%-a tej-, 35\%-a hús- és 19\%-a kettős hasznosítású (2019). Országosan a szarvasmarhafajták közül a holstein-fríz állománya a meghatározó, a magyarországi tejhasznú állomány 97\%-a ebbe a fajtába tartozik. A kettős hasznosításúakat túlnyomó többségében (99\%) a magyar tarka állománya teszi ki. A húshasznú fajtákat a legnagyobb arányban a limousine (23\%) és a charolais (18\%) fajták képviselik (KSH, 202Oa).

Magyarországon 2019 decemberében 100 hektár mezőgazdasági területre 17 szarvasmarha jutott. A mutató értéke megyénként 27 (Veszprém) és 8 (Heves) között szóródott (4. ábra). Hajdú-Bihar megye állt a második helyen (24 darab/hektár), míg Nógrád megye a harmadikon (23 egyed/hektár), vagyis háromszorosan haladták meg a Heves megyei értéket (KSH, 2020a).

A szarvasmarha - tenyésztés hazánk mezőgazdaságának egyik fontos ágazata, termékei mind a belső fogyasztói, mind az exportban értékesíthető árualapok előállításában nélkülözhetetlen. A mezőgazdasági ágazat egyik meghatározó termelési ága a szarvasmarha-tenyésztés és tejtermelés, amely a teljes mezőgazdasági kibocsátás egytizedét és az állattenyésztés termelési értékének közel egyharmadát teszi ki. 


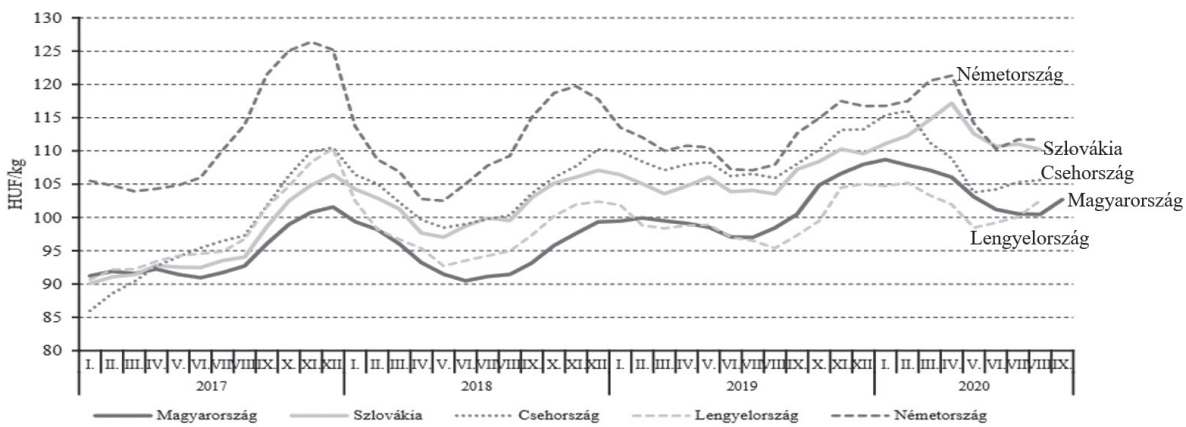

\section{3. ÁBRA}

A nyerstej havitermelői átlagára néhány európai országban (2017-2020)

FIG. 3

(The Average Monthly Producer Price of Raw Milk in Some European Countries (20172O2O)

Forrás (Source): AKI PÁIR, 2021

Megjegyzés (Note): Magyarország (Hungary); Szlovákia (Slovakia); Csehország (Czech Republic); Lengyelország (Poland); Németország (Germany)

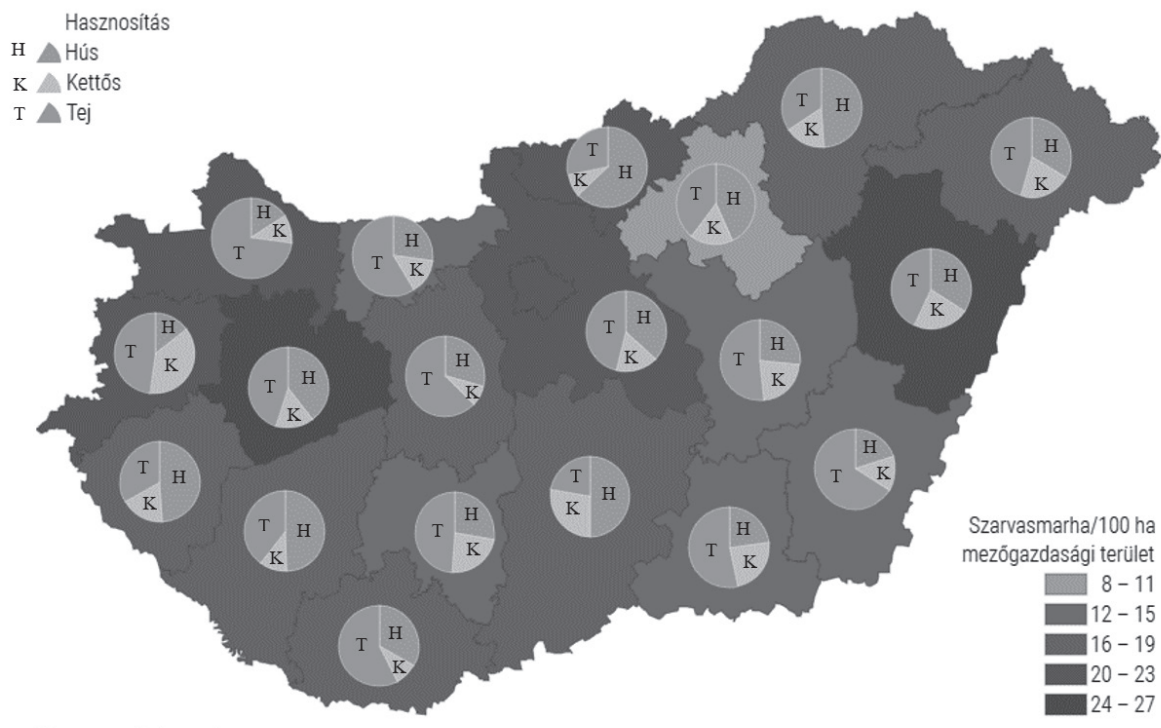

4. ÁBRA

Pest megye Budapesttel együtt.

A szarvasmarha-állomány megyei megoszlása hasznosítási típusonként, 2019 (County Distribution of Cattle Herd by Type of Utilization, 2019)

Forrás (Source): KSH, 2020B

Megjegyzés (Note): hasznosítás (production purpose); hús (beef); kettős (mix); tej (milk); szarvasmarha/10o ha mezőgazdasági terület (Cattle/1oo ha agricultural area) 
Hazánk 1988-ban érte el a tejtermelésének csúcsát, mely 2797 millió literre tehető, ebből az állami és szövetkezeti tejipar által történő tejnek a felvásárlása több mint 90\% volt. A 2004. évi uniós csatlakozáskor mért tényleges termelés 1845 ezer tonna volt. Magyarország tehéntejtermelése 2018-ban mintegy 1,535 millió tonna (KSH) volt (a TSzSz - Tej Szakmaközi Szervezet és Terméktanács - szerint ez mintegy 1,9 millió tonna), amivel így az uniós lista középmezőnyének végén foglalhattunk helyet. A rangsor első hat helyezettje mind 10 millió tonna felett termelt 2018-ban, Németországgal az élen, ahol közel 32,5 millió tonna volt az éves tehéntejtermelés. A rangsor első helyén Németország végzett, több mint 32 millió tonnás tehéntejtermelésével, őt követi Franciaország 24,5 millió tonnával, Nagy-Britannia (amely azóta már nem EU-tagállam) 15 millió tonnával és Hollandia 13,8 millió tonnával. Szintén 10 millió tonna feletti volt még a tehéntejtermelése 2018-ban Olaszországnak és Lengyelországnak is. A lista utolsó tíz helyezettjének mind 1 millió tonna alatt volt a tejtermelése két évvel ezelőtt, a legutolsó helyekre olyan országok kerültek, mint Luxemburg, Ciprus vagy Málta, ez utóbbinak mindössze 40 ezer tonna volt a tehéntejtermelése 2018-ban.

A magyar lakosság tej- és tejtermék fogyasztása - tejegyenértékben mérve - az uniós átlag (250 kg) alatti, $165 \mathrm{~kg}$ körül mozog egy fóre vetítve ezzel szemben az ideális mennyiség 250-270 kg/fó/év lenne. Ezen belül fogyasztói folyadéktejből 54-55 litert fogyasztott el átlagosan egy fó 2018-ban, savanyított tejtermékből (joghurt, kefir, tejföl) pedig 13-14 litert. A sajt és túró fogyasztás együtt 7,9 kg volt fejenként, míg vajból és vajkrémból 1,2 kg fogyott. A korábbi évekhez képest ezek a számok kismértékü emelkedést mutatnak, de még mindig elmaradnak az Európai Unió jelenlegi átlagfogyasztásától. A fogyasztói folyadéktej esetében a hazai fogyasztás elmaradás nem számottevő az uniós fogyasztáshoz képest, a feldolgozott, magas hozzáadott értékkel bíró tejtermékek fogyasztása ugyanakkor hazánkban jóval alacsonyabb. 2018-ban az egy főre jutó folyadéktejfogyasztás az EU-ban átlagosan 57 liter/fö/év volt, míg hazánkban 54,6 liter/fó/év.

A tehéntejtermelést tekintve azonban hazánk mindössze az uniós lista középmezőnyé- nek végén kapott helyet, kicsit több mint 1,535 millió tonnával. Habár így is olyan országokat előztünk meg, mint Litvánia, Szlovákia, Lettország, Bulgária, Horvátország, vagy akár Luxemburg, de az első öt helyezettől még nagyon el vagyunk maradva.

2017. év óta fokozatosan emelkedett az exportált élő szarvasmarha mennyisége, ugyanakkor csökkent az importé. 2019 novemberéig az export értéke meghaladta az 50 ezer tonnát, amit az elmúlt öt évben még egyszer sem sikerült elérni (5. és 6. ábrák).

A magyar élő szarvasmarha legfontosabb felvevő országai: Törökország, Ausztria, Koszovó, Horvátország és Oroszország. Ezek közül csak a Törökországba exportált mennyiség csökkent - mintegy 2 ezer tonnával - 2018 és 2019 között. Látványosan nőtt viszont az eladott szarvasmarhák mennyisége Ausztria és főleg Koszovó felé, azonban még így is Törökország maradt a legfontosabb külkereskedelmi partnerünk.

Tény, hogy a vizsgált 3 évben az élőszarvasmarha export, mind mennyiségben, mind értékben meghaladta az importot, de a marhahús esetében az export már rendre elmaradt az importtól.

\section{2. Üzemgazdasági jelentőség - Economic Significance}

A kisüzemi tejtermelés jelentősége a magyar szarvasmarhatartásban az elmúlt évtizedekben csökkent. A hazai tejtermelésben meghatározó a nagyüzemi és az iparszerü technológia. A világon és Európában jellemző szerkezeti struktúrától eltérốn a megtermelt tej több mint 80\%-a nagy tehénlétszámú telepekről származik és hazánkban az egyik legnagyobb az egy telepre jutó tehenek száma (HOLLÓ és SZABÓ, 2011). A mérethatékonyság szempontjából tehát nemzetközi szinten komparatív előnyünk van, ami várhatóan a jövooben is fennmarad.

A hazai tejtermelésben kardinális kérdés a tartás- és takarmányozástechnológia (annak színvonala), az üzemméret, valamint a takarmánytermelési és tartósítási kérdések, hiszen a magyarországi üzemek többségére e téren mutathatók ki elmaradások. A tejhasznú szarvasmarha-tenyésztésnek az állattenyésztési ágazatok közül a legnagyobb a fajlagos tartósan 


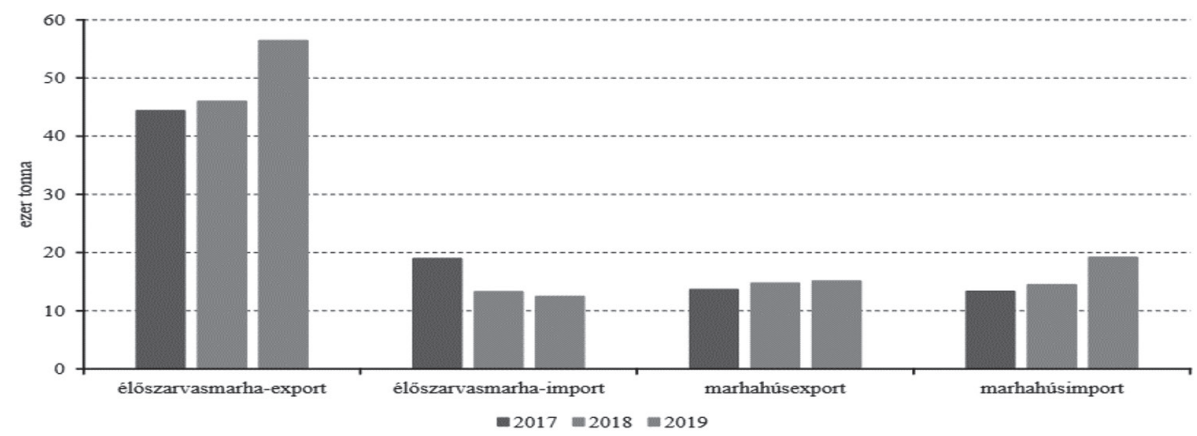

5. ÁBRA

FIG. 5

Élő szarvasmarha és a marhahús küllkereskedelmének mennyisége Magyarországon (20172019)

(Volume of International Trade in Live Cattle and Beef in Hungary (2017-2019))

Forrás (Source): AKI, 2019

Megjegyzés (Note): ezer tonna (thousand tons), élő szarvasmarha-export (live cattle export); élő szarvasmarha import (live cattle import); marhahúsexport (beef meat export); marhahúsimport (beef meat import)

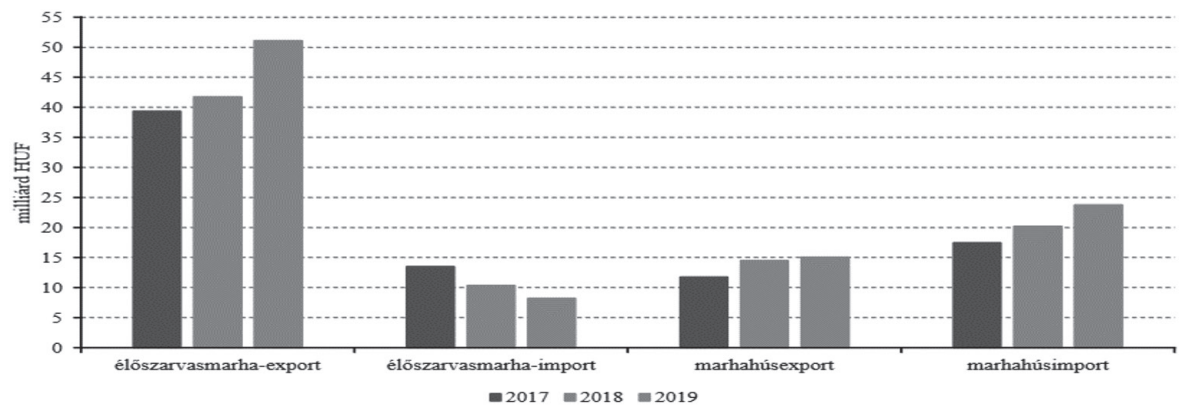

6. ÁBRA

\section{Az élő szarvasmarha és a marhahús külkereskedelmének értéke Magyarországon (2017-2019)}

(Value of International Trade in Live Cattle and Beef in Hungary (2017-2019)

FIG. 6

Source): AKI, 2019

Megjegyzés (Note): ezer tonna (thousand tons), élő szarvasmarha-export (live cattle export); élő szarvasmarha import (live cattle import); marhahúsexport (beef meat export); marhahúsimport (beef meat import)

lekötött eszközigénye. Az egy tehénre jutó átlagos telepérték újkori értéken 1,6-1,8 millió Ft, amit tovább növel a tenyészállatok (tehénállomány) és a takarmánytermő terület, valamint az ahhoz kapcsolódó géppark tőkeigénye. Ezen túl tartósan lekötött forgóeszközként jelennek meg a növendékállatok és az egész évre betárolt takarmány-készlet. A rendelkezésre álló tejtermelő kapacitások nagy része elavult, amely gátja a hatékony termelésnek.

A tejtermelés termelési költségekének legnagyobb hányadát a takarmányköltségek teszik ki. Magyarországon alapvetően extenzív gyepgazdálkodás folyik, amelynek hozamai jelentősen elmaradnak a nyugat-európai országokétól. Ezért egyrészt viszonylag magas a széna önköltsége, másrészt a takarmányozástechnológiából szinte teljes mértékben kimarad a legeltetés. Ezen túl a monodiétás takarmányozásban a kukoricaalapú abraktakarmány túlsúlya jellemző, amely a volatilis takarmányalapanyag árakon keresztül kiszolgáltatottá teszi az ágazatot. Sőt, a kukoricatúlsúly (szemes- és silókukoricára épülő takarmányozási rendszer) rontja a szaporodásbiológiai mutatókat, így magas selejtezési arányt, egyúttal rövid hasznos élettartamot (1,8-2,2 év/tehén) okoz, amely szintén növeli az önköltséget a „kvázi” 
kihasználatlan tenyészállatértéken keresztül. Mint minden gazdasági tevékenységnek, a tejtermelésnek vannak üzemgazdasági szem- pontból kiemelendő előnyei és hátrányai melyeket a 1. táblázatban foglaltunk össze.

\section{TÁBLÁZAT}

A tejtermelés üzemgazdasági előnyei és hátrányai (Economic Advantages and Disadvantages of Milk Production)

\begin{tabular}{l} 
Üzemgazdasági előnyök \\
\hline - Nyílt ciklusú termelési folyamat, amely során folya- \\
matos árbevétel realizálható. Ez kedvező likviditási \\
helyzetet és gyors forgóeszköz körforgást eredményez. \\
- Az állatitermék-elóállító ágazatok közül a tejtermelés- \\
ben a legjobb a takarmány-transzformáció. \\
- Az ágazat jól hasznosítja a tömegtakarmányokat, \\
kevésbé érzékeny a gabonaárak változására. \\
- Az abrakfogyasztó ágazatokhoz képest alacsonyabb és \\
olcsóbb a fehérjeigény. \\
- Egyes korcsoportok takarmányozása legeltetésre is \\
alapozható, amely csökkenti a takarmányozási költsé- \\
geket. \\
- Jelentős szerves-trágya termelés (8-16 tonna/te- \\
hén/év), amely tápanyag-gazdálkodási szempontból \\
kedvező, nem okoz környezetvédelmi gondot annak \\
elhelyezése és felhasználása. \\
- Folyamatos foglalkoztatást biztosít, ami vidékfejlesz- \\
tési és foglalkoztatási oldalról tekintve kedvező. \\
- Kiforrott technológiai rendszerek állnak rendelke- \\
zésre. \\
- Magas fedezeti összege (rezsibíró képesség) révén \\
kiemelt jelentőségű a vegyes szerkezetű komplex mező- \\
gazdasági vállalkozásokban. \\
- Az ágazatban jelentős összegű közvetlen és horizontá- \\
lis támogatások érhetőek el.
\end{tabular}

Üzemgazdasági hátrányok

- Jelentős az ágazat befektetett tóke igénye (telephely, istállók, fejőház, technológiai berendezések, tenyészállat stb.). - Ennek többsége speciális eszköz, amely merevíti a gazdálkodás szerkezetét és hosszú időre meghatározza a termelés irányát és kereteit.

- Viszonylag alacsony eszközhatékonysággal jellemezhető.

- Jelentős az ágazat takarmánytermő terület igénye (o,6-1,1

ha/számosállat AK függvényében).

- Viszonylag magas az ágazat forgótőke igénye, és annak jelentôs része tartósan le van kötve (pl. tenyészutánpótlás, egész évre betárolt takarmányok).

- Ebből következően lassú a forgóeszközök forgási sebessége. - A szarvasmarhára nagy generációs intervallum és alacsony szaporaság (egyet ellő, unipara) jellemző.

- Ebból adódóan viszonylag rugalmatlan, a piaci viszonyok változásaira lassan reagál.

- Intenzív körülmények között rövid a tejelő tehenek hasznos élettartama.

- Viszonylag magas az ágazat élőmunka igénye és folyamatos, többmüszakos munkarend kialakítása szükséges.

- Erősen ingadozó árak, gyakori piaci zavarok jellemzik az ágazatot.

- A termékpályán alacsony a termelői szerveződés és összefogás színvonala.

\section{Economic advantages}

- Open cycle production process, during which continuous sales revenue can be realized. This results in a favorable liquidity situation and fast current asset turnover.

- Among the animal production sectors, feed transformation is the best in milk production.

- The sector makes good use of forage and is less sensitive to changes in grain prices.

- Protein demand is lower and cheaper compared to another grain consuming animal husbandry sectors.

- Feeding for some age groups can also be based on grazing, which reduces feeding costs.

- Significant production of organic manure (8-16 tons / cow / year), which is favorable from the point of view of nutrient management, does not cause environmental problems in its placement and use.

- Provides continuous employment, which is favorable from the point of view of rural development and employment.

- Efficient technology systems are available.

- Due to its high margin amount (resilience) it is of paramount importance in mixed-structure agricultural enterprises.

- A significant amount of direct and horizontal support is available in the sector.

\section{Economic disadvantages}

- There is a significant need for capital investment in the sector (farm, barns, milking house, technological equipment, breeding animals, etc.).

- Most of this is a special equipment that stiffens the structure of farming and determines the direction and framework of production for a long time.

- Characterized by relatively low asset efficiency.

- There is a significant need for forage area in the sector (o.6-1.1 ha / number of animals depending on land quality).

- The sector's demand for current assets is relatively high and a significant part of it is permanently fixed (eg. breeding livestock, fodder stored throughout the year).

- As a result, the rotational speed of the current assets is slow.

- Cattle is characterized by a large generation interval and low fertility (single born, unipara).

- As a result, it is relatively inflexible and responds slowly to changes in market conditions.

- Under intensive conditions, the useful lifetime of dairy cows is short.

- The demand for living labor in the sector is relatively high and a continuous, multi-shift work schedule is required.

- The sector is characterized by highly fluctuating prices and frequent market disturbances.

- The level of producer organization and cooperation willingness in the product line is low.

Forrás (Source): Saját szerkesztés, 2021 (Authors'own compilation, 2021) 


\subsection{1. Ágazati naturális mutatók - Sectoral Natural Indicators}

Ugyan hazánkban a tejtermelés mennyiségi hatékonysága (egy tehénre jutó éves tejtermelés) a versenytárs országokhoz képest jó (a magyar átlag 7833 liter/tehén/év, mely hatékony nagygazdaságokban meghaladja a 11 ooo liter/ tehén/év-es szintet), viszont nem szabad azt elfelejtenünk, hogy a jelenleg alkalmazott genetikai potenciállal nem tudunk e tekintetben elöre lépni. Amíg a tenyésztés és az árutermelés nem válik el egymástól, addig ez a hatékonyságbeli korlát a jövőben is megmarad.

A tejtermelés üzemi szintű naturális és gazdasági hatékonyságának alakulásában igen jelentős szerepe van a humán erőforrásnak is. Egyrészt hazánkban relatíve alacsony a munkaerő hatékonysága (egy gondozóra átlagosan 20-21 tehén jut), amely sok esetben technológiai színvonallal is összefüggésbe hozható, másrészt a mezőgazdaságban, de különösen az állattenyésztésben általános probléma az alacsony munkaerőkínálat. Ez utóbbi mennyiségi és minőségi értelemben egyaránt igaz. Az emberek szó szerint nem akarnak állattenyésztéssel foglalkozni, abban dolgozni, s az oktatásban is nagyon kevés fiatal választja ezt a szakmát.

A hazai tejhasznosítású szarvasmarha-tenyésztés az elmúlt évtizedekben a szakosodás és a specializált termelés eredményeként a nemzetközi élvonalba került. A megtermelt tej fajlagos mennyiségét illetően európai, de világ összehasonlításban is kiválóan teljesítünk, az egy tehénre jutó tejtermelésben Magyarország a legjobb tíz ország között található. E paraméterben a jövőben nem várható előrelépés, úgy gondoljuk, a korábban jelzett gondok miatt ezen mutató túlzott hajszolása nem szerencsés. Látszik ugyanakkor a lemaradásunk a tej összetételében akár a zsír, akár a fehérje ter- melést vesszük alapul. E területen a részleges fajtaváltás, a keresztezések nagyobb mértékü elterjedése és a takarmányozási technológia módosítása eredményes lehet. Ki kell használnunk az ellenőrzött tehenek arányában mutatkozó előnyünket és a tejtermelés ellenőrzést a kisebb állományokra is ki kell terjeszteni (2. táblázat).

Jelentős tartalékkal rendelkezünk a jelenleg 440 napot meghaladó két ellés közötti időben. Bár a legtöbb kiemelkedő termelésű országban 400 nap felett alakul ez a paraméter, a magyar tejtermelés e tekintetben akár 10-20 napos tartalékkal is rendelkezik. A nagyobb termelési színvonalon dolgozó kanadai, holland, vagy akár német tenyészetek is tudják a 420 nap körüli két ellés közötti időt. A megoldást itt is a technológiához és takarmányozási háttérhez igazodó termelési színvonal megválasztása, a megfelelő szaporodásbiológiai menedzsment kialakítása és e területen a szakemberképzés jelentheti.

A hasznos élettartam nem csak hazánkban, hanem minden kiemelkedő fajlagos hozammal termelő országban rendkívül alacsony, így jelentős javulás a 2,2-es teljesített laktációszámban nem várható. A Holstein-fríz Tenyésztők Egyesületének tenyésztési programja, a küllemre és a hasznos élettartamra irányuló szelekció ezt célozná, de a külföldi tapasztalatok alapján e területen nem igazán várható előrelépés. Tenyésztési és gazdaságossági szempontból fontos mutató lehet a tehenek első elléskori életkora. A tejhasznosítású fajták, így a holstein-fríz is alkalmas a korai tenyésztésbe vételre és megfelelő üszőnevelési technológiával 24 hónapos korra a tehenek leellethetők. Nemzetközi összehasonlításban 1-2 hónapos lemaradásunk van, aminek oka egyértelmúen a nem megfelelő üszőnevelési technológia és az ezt megalapozó szaktudás. 
KovÁcs, K. - VidA, V. - MADAI, H. - Szúcs, I.

2. TÁBLÁZAT

Néhány vezető tejtermelő ország adatainak összehasonlítása

(Comparison of Indicators from Some Leading Dairy Countries)

\begin{tabular}{|c|c|c|c|c|c|c|c|c|}
\hline Ország (Country) & 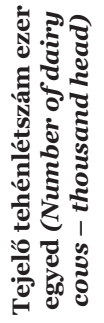 & 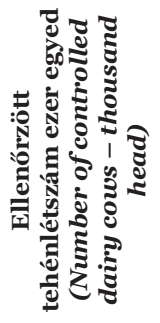 & 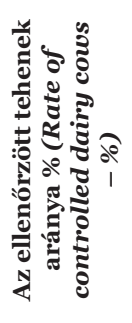 & 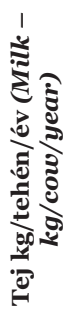 & 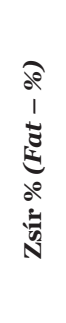 & 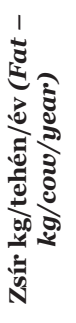 & 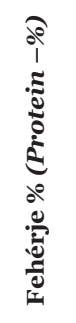 & 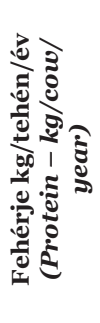 \\
\hline Belgium (Belgium) & 205 & 57 & 28 & 7737 & 3,94 & 305 & 3,30 & 256 \\
\hline Dánia (Denmark) & 597 & 363 & 60 & 9661 & 4,09 & 395 & 3,38 & 327 \\
\hline Finnország (Finland) & 283 & 90 & 32 & 9518 & 3,77 & 313 & 3,29 & 396 \\
\hline Franciaország (France) & 3600 & 1681 & 46 & 7905 & 3,87 & 306 & 3,11 & 245 \\
\hline Németország (Germany) & 4267 & 2123 & 50 & 9092 & 4,06 & 369 & 3,37 & 307 \\
\hline Olaszország (Italy) & 1850 & 1099 & 61 & 9232 & 3,71 & 347 & 3,32 & 306 \\
\hline Hollandia (the Netherlands) & 1553 & 579 & 38 & 8767 & 4,27 & 374 & 3,46 & 303 \\
\hline Spanyolország (Spain) & 851 & 492 & 57 & 9546 & 3,65 & 349 & 3,20 & 306 \\
\hline Svédország (Sweden) & 267 & 141 & 54 & 9764 & 4,10 & 400 & 3,38 & 330 \\
\hline Egyesült Királyság (the UK) & 1812 & 1465 & 80 & 9091 & 3,93 & 357 & 3,16 & 287 \\
\hline Magyarország (Hungary) & 250 & 172 & 69 & 8988 & 3,70 & 332 & 3,28 & 295 \\
\hline
\end{tabular}

Forrás (Source): BÉRI, 2015

Az egyes termelési mutató szempontjából hazánk tipikusnak mondható üzeme a középmezőnybe tartozik nemzetközi szinten (3. táblázat), de a nagyméretü üzemeink termelési mutatói a felső legjobb 25\%-közé tartozik.

Jelenleg a magyarországi tejhasznú állomány mintegy 92\%-a Holstein-fríz és keresztezett, aminek jelentősége nemzetközi szinten is hasonló. Az egyéb tejhasznú fajták (pl. Jersey, Brown-swiss stb) szerepe jelenleg nem számottevő. A hazai tejhasznosítású szarvasmarha-tenyésztés az elmúlt évtizedekben a szakosodás és a specializált termelés eredményeként a nemzetközi élvonalba került. Magyarország az egy tehénre jutó tej mennyiségét és higiéniai paramétereit illetően európai, de világ összehasonlításban is kiemelkedő helyen áll. E paraméterekben a jövőben nem várható jelentősebb javulás. Ugyanakkor a megtermelt tej beltartalmi paraméterei (3,6\% zsír, 3,3\% fehérje) elmaradnak az uniós átlagtól, jelenleg a mennyiségi szemlélet a mérvadó a minőségivel szemben. E területen a részleges fajtaváltás, a keresztezések nagyobb mértékű elterjedése és a takarmányozástechnológia módosítása hozhat előrelépést. 
3. TÁBLÁZAT

TABLE 3

Néhány termelési hatékonysági mutató egyes átlagos méretű tipikus tejtermelö üzemnél az IFCN saját adatbázisa alapján 2017-ben

(Some Production Efficiency Indicators for Some Average-Sized Typical Dairy Farms Based on IFCN's Own Database in 2017)

\begin{tabular}{lcccccc}
\hline \multicolumn{1}{c}{ Ország (Country) } & & & & &
\end{tabular}

Forrás (Source): IFCN, 2018

Megjegyzés (Note): *4\% zsír- és 3,3\% fehérjetartalomra standardizált ( ${ }^{*} 4 \%$ fat and $3.3 \%$ protein standardised measures)

A hazai tejtermelésben az elmúlt időszak negatív tendenciái ellenére meghatározó a nagyüzemi és az iparszerü technológia, valamint az ezzel előállított tej aránya. A hatékony nagyüzemi tejtermelésben terjedő müszaki megoldások között megtalálhatók a precíziós állattenyésztésben alkalmazott takarmányozástechnológiai és fejési technológia újításai is. Elsősorban a keverő-kiosztó robotizált technológiák terjedtek el, amelyek a kiosztás gyakorisága és a homogén adagok kiosztása révén biztosítják a szakszerü ,jászolmenedzsmentet” HÚTH és munkatársai (2019). Természetesen maga a takarmány előállítás és beszerzés, illetve az optimális összetétel és beltartalom biztosítása elsődleges feladat a takarmánymenedzsmentben. A világon és Európában jellemző szerkezeti struktúrától eltérően a megtermelt tej több mint 80\%-a nagy tehénlétszámú tele- pekről származik és az egy telepre jutó tejtermelő tehenek számával - ami meghaladja a 350-et -, a legtöbb uniós országot megelőzzük. Ezt a létszámot csak néhány volt szocialista ország tudja megközelíteni, míg a régi Európai Uniós tagállamokban ez általában nem éri el a 150 egyedet. A nagyüzem meghatározó szerepét mutatja az a paraméter is, hogy az egy tenyészetre jutó napi tejtermelés meghaladja a $7700 \mathrm{~kg}$-ot és ebben is elöl vagyunk. A magyarországi szarvasmarha telepek mindössze 5\%-át nevezhetjük igazán nagyüzeminek, de a megtermelt tej több mint 80\%-át ilyen telepen állítják elő. A hatékonyság szempontjából meglévő helyzeti előnyünk várhatóan a továbbiakban is fennmarad és az üzemi struktúrát tekintve hazánkban a tejtermelés meghatározó részét az elkövetkezendő években is a nagyüzem fogja adni. 


\section{ADAT- ÉS INFORMÁCIÓGYƯJTÉS, MÓDSZERTAN - DATA COLlECTION, MATERIAL AND METHOD}

A munka elsődlegesen a deduktív (analitikus) és induktív kutatási stratégiát követi, vagyis a következtetések során az általánosból az egyedire, és az egyediből az általánosra következtetünk. A forrásokat, dokumentumokat és eddigi tapasztalatokat elemezve fogalmazzuk meg az ok-okozati összefüggéseket, a megfogalmazott javaslatok/koncepciók megvalósíthatóságát és továbbfejlesztését. Használtuk a tartalomelemzést, amely olyan kutatási módszer, ami lehetővé teszi egy anyag elemzését oly módon, hogy annak minden komponensét figyelembe veszi. Áttekintjük a témával kapcsolatos egyéb dokumentumok (pl. vitaanyagok, tanulmányok, statisztikai, jelentések, stb.) körét is.

Az üzemtani elemzések során a technológiából indulunk ki, így elemző módon bemutatjuk a különböző hatékonysági mutatókkal jellemzett jelenleg elérhető ún. ,jó színvonalú termelési gyakorlatot" és kereszttábla elemzésekkel szemléltetjük az egyes ható tényezők potenciális hatását a legfontosabb ökonómiai mutatókra.

A vizsgált ágazatok specifikumaiból adódóan a kutatásunkban felhasználandó adatok két fő csoportra oszthatók: (1) a termelés éves költség-jövedelem viszonyainak elemzéséhez szükséges adatok; (2) a zöldmezős beruházások esetében a beruházási költségek meghatározásához szükséges adatok és információk. Az éves költség-jövedelem viszonyok értékeléséhez a következő termelési adatok összegyưjtésére volt szükség:

- a felhasznált ráfordítások (anyagok, élőmunka, gépi munka) naturális mennyisége;

- a ráfordítások egységárai (inputárak);

- minden egyéb, a termelési sajátosságokkal összefüggő ráfordítás, és annak költsége;

- a fajlagos hozamok;

- a különböző termékek értékesítési árai.

A kutatás során a vizsgálat célkitűzésének megvalósítása érdekében személyes üzemlátogatásokra került sor, melynek keretében több hazai vállalkozásnál történt adat- és informá- ciógyújtés. A termelőüzemi adatgyújtés személyes üzemlátogatáson és szakmai konzultáción alapszik. Az adatgyújtést nehezítette, hogy a termelő vállalkozások nagy része nem tud megbízható és pontos adatokat szolgáltatni az üzemgazdasági nyilvántartások hiánya miatt, valamint a számviteli nyilvántartások nem megfelelő szerkezetben, egyöntetúen tartalmazzák az adatokat, és gyakran hiányoznak a megfelelő bontású ágazati elszámolások is. Az említett problémák miatt, az összehasonlítás érdekében célszerú volt egy termelő üzemi primer adatokból létrehozott szimulációs modellezésen alapuló elemzés elkészítése, melyhez a szükséges adatokat saját adatbázis megteremtésével kaptuk meg. A költségoldal elemzését nem lehetett pusztán a költségadatok begyújtésére alapozni, ezért a teljes termeléstechnológia naturális ráfordítások formájában való felvételezésére és felállítására volt szükség. A vizsgálathoz szükséges további adatokat - a termelői adatok mellett - különböző az ágazathoz kötődő tanulmány és hazai adatbázisok szolgáltatták. Az adatgyújtés során megismert termeléstechnológiához kapcsolódóan, más forrásból beszerzett inputárakkal (pl. AKI, stb.) termelési költségeket képeztünk. Ennek oka, hogy a termelők a beszerzendő tételek költségeiről nem, de az általuk egész évben végzett kézi és gépi munkákról, valamint ezek fajlagos teljesítményéről, a felhasznált anyagokról és ezek mennyiségéről naturáliákban pontos tájékoztatást tudtak adni. A hozamadatok a termelő üzemektól, az értékesítési árakra vonatkozó adatok termelő és kereskedő vállalkozásoktól, illetve szekunder forrásokból származnak. Fontos kiemelni, hogy minden output és input ár nettó formában, azaz ÁFA nélkül értendő. Az input- és outputárak alapvetően a 2019. évi árszínvonalat tükrözik.

$\mathrm{Az}$ összegyüjtött adatokat Excel alapú, determinisztikus szimulációs modell használatával elemeztük. Az üzemgazdasági értékeléshez a következő elemzési módszereket alkalmaztuk: (1) költség-haszon elemzés; (2) beruházás-gazdaságossági elemzés és (3) érzékenységvizsgálatok. Érzékenységvizsgálatokon belül a termelés hatékonyságára, illetve gazdaságosságra leginkább hatással lévő tényezőkre szcenárió-elemzéseket végeztünk.

A determinisztikus szimulációs modell se- 
gítségével megalkotott ún. virtuális gazdaság egy jó termelési színvonalon, azaz „good practice” kategóriába tartozó vállalkozás lett. A cél ugyanis nem az adatszolgáltató vállalkozások, hanem a vizsgált ágazatok elemzése volt. A fóbb módszertani-kalkulációs peremfeltételek a fenti elveknek megfelelően a következőképpen foglalhatók össze:

- Az inputárak 2019. évi árszínvonalat tükröznek, az árak nettó módon, ÁFA nélkül értendők.

- A fajlagos munkabér-költségek vonatkozásában a 2019. évi bérszínvonalhoz igazodó bérköltséggel számoltunk.

- Az ágazatra terhelt általános költségek az adatgyưjtésünk alapján becsült értéknek tekinthetők (a közvetlen költségek 9-11\%ában határoztuk meg), mindamellett, hogy egy adott vállalkozás méretétől, termelési szerkezetétől, berendezkedésétől, stb. függően ettől eltérő értékekkel is találkozhatunk a gyakorlatban.

- A terméshozamok és az értékesítési árak 2019. évi árszínvonalat tükröznek, az értékesítési árak nettó módon, ÁFA nélkül értendők.

- Az egy átlagos évre vonatkoztatott költség-jövedelem elemzés esetében ágazati szintű jövedelemkategóriát (fedezeti összeg) és általános költségekkel együtt értelmezett vállalkozásszintű jövedelemkategóriát (nettó jövedelem) is meghatároztunk, melyek minden esetben adózás előtti eredménykategóriáknak tekintendők, vagyis nyereségadó-fizetési kötelezettséget nem vettük figyelembe.

A beruházás gazdaságosságának értékelésére 10 éves időtartamot figyelembe véve, négy dinamikus mutatót használtunk: (1) Nettó jelenérték (NPV); (2) Belső megtérülési ráta (IRR); (3) Jövedelmezőségi index (PI) és (4) Diszkontált megtérülési idő (DPP).

Az anyag elkészítése során fontosnak tartottuk nemzetközi dimenzióba is elhelyezni az ágazatot, hogy ez által jobban megérthessük, milyen versenyhátránnyal küzdenek a magyarországi szereplők. Ehhez elsősorban szakirodalmi források voltak a segítségünkre. A hazai helyzet szemléltetéséhez a NAIK AKI és a KSH adatbázisaira támaszkodtunk.

A Magyarországon belüli ágazati elemzés során is többféle adatbázist használtunk. E részekben bemutatásra kerültek a KSH és a NAIK AKI vonatkozó adatai, de az ágazat külkereskedelmének elemzéséhez szintén a KSH adatait használtuk. Külön kiemeljük, hogy az összehasonlítások esetében nagymértékben támaszkodtunk a NAIK AKI által müködtetett Tesztüzemi Rendszer ${ }^{1}$ alapján publikált alapadatokra.

Hangsúlyozzuk, hogy a bemutatott kalkulációk nem fogadhatók el egyetlen igazságként, nem vonatkoznak minden vállalkozásra és minden évre, hiszen a költség-, hozam- és árviszonyok az egyes vállalkozások között nagyon jelentős eltéréseket, változékonyságot mutathatnak. Vizsgálataink statisztikai értelemben nem reprezentatívak, de a nagyságrendek tekintetében szakmailag hűen és korrekten jellemzik a termelés ökonómiai viszonyait a tejtermelés esetében.

\section{EREDMÉNYEK - RESULTS}

\subsection{Jó termelési színvonalon gazdálkodó tejtermelő virtuális üzem - A Virtual Dairy Farm with Good Production Standards}

Az üzemgazdasági elemzés alapján egy (a hazai átlagos termelési mutatószámok alapján) jó színvonalon gazdálkodó virtuális modelltelep került kialakításra, mely a Magyarországon szinte kizárólagos iparitejtermelésre használt fajtával a holstein-frízzel dolgozik. A modellkalkulációban egy jó termelési színvonalon termelő közepes méretü üzem gazdasági teljesítményét értékeljük. Az üzemben 740 holstein-fríz tehén biztosítja a termelést, a teljes szarvasmarha állomány összesen 1689 állatot jelent. A technológiai paraméterek között talán a legfontosabb az egy tehén által megtermelt tej mennyisége, mely ezen üzem esetén átlagosan 11 ezer liter/tehén/év volt. Ez a mutató-

1A Mezőgazdasági Számviteli Információs Hálózat (Farm Accountancy Data Network, rövidítve: FADN; magyar rövidítése: MSzIH) a mezőgazdasági üzemek pénzügyi-, vagyoni helyzetét felmérő Európai Uniós reprezentatív információs rendszer. Magyarországi alrendszere a Tesztüzemi Információs Hálózat, ismertebb nevén Tesztüzemi Rendszer. 
szám, az Európai Unióban is igen jónak számít, telepi átlag tekintetében. A holland, a német, francia és az olasz telepek legjobbjai tudnak ilyen termelési színvonalat. A mutatószámok ágazati szakértők véleménye alapján kerültek kialakításra, terjedelmi korlátok miatt nem kerül részletezésre minden egyes mutató esetében, hogy a hazai átlagok hogyan is alakulnak.

Az egy tehénre jutó termelés növelésének feltétele a precíziós tejgazdálkodás elemeinek alkalmazása, melynek fó célja az állat egyedi teljesítményének maximalizálása, a betegségek korai felismerésével és a gyógyszeres kezelés minimalizálásával, ami a megelőző egészségügyi intézkedések révén érhető el. A precíziós tejgazdálkodási technológiák előnyei közé tartozik a hatékonyságnövelés, a költségek csökkentetése, a jobb termékminőség, a káros környezeti hatások minimalizálása, valamint az állatok egészségének és jólétének javítása. is (BEWLEY, 2010). A hazánkban közepes méretűnek minősülő magas színvonalon termelő üzem egyes technológiai paramétereit a 4. táblázat mutatja.

4. TÁBLÁZAT

Jó színvonalú tejtermelő tehenészeti telep fóbb termelési- és technológiai mutatói (A Good Quality Dairy Farm's Main Production and Technology Indicators)

\begin{tabular}{|c|c|c|}
\hline Megnevezés (Desctiption) & $\begin{array}{c}\text { Mértékegység } \\
\text { (Measuring } \\
\text { unit) }\end{array}$ & $\begin{array}{l}\text { Érték } \\
\text { (Value) }\end{array}$ \\
\hline Fajta (Breed) & - & holstein-fríz \\
\hline Átlagos tehén létszám (Average number of cows) & egyed (head) & 740 \\
\hline Átlagos állományi létszám (Average livestock number) & egyed (head) & 1689 \\
\hline Fajlagos éves tejhozam (Specific annual milk yield) & kg/év (kg/year) & 11000 \\
\hline Hízómarha napi súlygyarapodás (Daily weight gain of cattle for fattening) & $\mathrm{kg} / \mathrm{nap}(\mathrm{kg} /$ day $)$ & 0,85 \\
\hline Extra minőségű tej aránya (Extra quality milk ratio) & $\%$ & 98 \\
\hline Tartási mód (Housing system) & - & $\begin{array}{l}\text { kötetlen } \\
\text { pihenóboxos } \\
\text { (resting box) }\end{array}$ \\
\hline Selejtezési arány (Culling rate) & $\%$ & 30,2 \\
\hline Tehenek hasznos élettartama (Useful life of cows) & laktáció (lactation) & 2,2 \\
\hline Borjúszaporulat (Calf reproduction) & $\%$ & 81,3 \\
\hline Két ellés között eltelt idő (Time between calving) & nap (days) & 432 \\
\hline Hizlalási végsúly (hízó marha) (Final fattening weight -for fattening cattle) & $\mathrm{kg} / \mathrm{db}(\mathrm{kg} / \mathrm{head})$ & 511 \\
\hline $\begin{array}{l}\text { Korcsoportok száma (hozam és takarmányozás szerint) (Number of age groups } \\
\text { (by yield and feed) }\end{array}$ & $\mathrm{db}$ (piece) & 9 \\
\hline Telepi dolgozói létszám (Number of famr labour) & fö (head) & 27 \\
\hline
\end{tabular}

Forrás (Source): Saját szerkesztés, 2020 (Authors'own compilation, 2020)

\subsection{Ráfordítások és termelési költségek - Expenses and Production Costs}

A modellszámítás során a vizsgált jó színvonalon termelő tejelő tehenészeti telep legfőbb alapadatait és technológiai paramétereit az 5 . táblázat mutatja. A telepen 9 korcsoport takarmányozása folyik, az itatásos borjú, a kétféle növendék üsző korcsoport, termelési szint szerint különböző tehén, illetve a hízlalásra fogott bikaborjak korcsoportja. A tehenészet részesül a különféle termeléshez kötött és termeléstől elválasztott hazai és Európai Uniós támogatásokból.

A tejtermelésben felhasznált anyagok részben vásárolt, részben pedig a gazdaságban termelt termékek. A vásárolt termékeket a költségszámításban beszerzési áron értékeltük, a saját termelésű termékeket (tömegtakarmányok) pedig önköltségi áron.

A tejtermelésben az egyik legjelentősebb költségtétel a takarmányozás költsége, mely 


\section{TÁBLÁZAT}

TABLE 5

\section{Jó színvonalú tejtermelô tehenészeti telep gazdasági alapadatai, fajlagos mutatói} (Basic Economic Indexes of a Good Quality Dairy Farm, Specific Indicators)

\begin{tabular}{|c|c|c|}
\hline Megnevezés (Desctiption) & $\begin{array}{l}\text { Mértékegység } \\
\text { (Measuring unit) }\end{array}$ & $\begin{array}{l}\text { Érték } \\
\text { (Value) }\end{array}$ \\
\hline Nyerstej értékesítési ára (Sales price of raw milk) & $\mathrm{Ft} / \mathrm{kg}$ & 100 \\
\hline Hízómarha értékesítési ára (Sales price of cattle for fattening) & $\begin{array}{l}\text { Ft/kg élősúlyban (Ft/live } \\
\text { weight) }\end{array}$ & 600 \\
\hline Növendék üsző értékesítési ára (Sales price of young heifers) & $\begin{array}{l}\text { Ft/kg élösúlyban (Ft/live } \\
\text { weight) }\end{array}$ & 510 \\
\hline Selejt tehén értékesítési ára (Sales price of culled cows) & $\begin{array}{l}\text { Ft/kg élősúlyban (Ft/live } \\
\text { weight) }\end{array}$ & 326 \\
\hline \multicolumn{3}{|l|}{ Takarmányárak (Feed prices) } \\
\hline Itatásos borjú (napi átlagos) (Young calf(daily average)) & Ft/adag (Ft/portion) & 1369 \\
\hline Növendék üsző (napi átlagos) (Adult heifer (dairly average)) & Ft/adag (Ft/portion) & 409,5 \\
\hline $\begin{array}{l}\text { Tehén } 40 \text { literes hozammal (napi átlagos) (Cow with a yield of } 40 \text { liters } \\
\text { (daily average)) }\end{array}$ & Ft/adag (Ft/portion) & 1682,4 \\
\hline $\begin{array}{l}\text { Tehén } 28 \text { literes hozammal (napi átlagos) (Cow with a yield of } 28 \text { liters } \\
\text { (daily average)) }\end{array}$ & Ft/adag (Ft/portion) & 1169,7 \\
\hline Hízómarha (napi átlagos) (Fattening cattle (daily average)) & Ft/adag (Ft/portion) & 1169,7 \\
\hline Átlagos takarmányár (Average feed price) & $\mathrm{Ft} / \mathrm{kg}$ & 373 \\
\hline $\begin{array}{l}\text { Átlagos bruttó órabér (telepi dolgozó) (Average gross wage per hour } \\
\text { (physical worker)) }\end{array}$ & Ft/óra (Ft/hour) & 1202 \\
\hline Átlagos bruttó órabér (telepvezető) (Average gross wage per hour (manager)) & Ft/óra (Ft/hour) & 1800 \\
\hline Állategészségügyi költségek (Veterinary costs) & Ft/tehén (Ft/dairy cow) & 15575 \\
\hline Értékcsökkenési leírás (Depreciation) & $\begin{array}{l}\text { Ft/tehén/év (Ft/dairy } \\
\text { cow/year) }\end{array}$ & 164000 \\
\hline Általános költségek¹ (Overheads) & $\begin{array}{l}\text { Ft/tehén/év (Ft/dairy } \\
\text { cow/year) }\end{array}$ & 89500 \\
\hline Tejkvóta támogatás (Milk quota support) & Ft/bázis kg (Ft/base kg) & 5,43 \\
\hline $\begin{array}{l}\text { Termeléshez között tejhasznú tehén támogatás (Dairy cow suport for } \\
\text { production) }\end{array}$ & Ft/egyed (Ft/animal) & 108877 \\
\hline $\begin{array}{l}\text { Hízottbikatartás támogatás (EU + nemzeti forrás) (Fattening bull support } \\
(\text { EU+national source)) }\end{array}$ & Ft/egyed (Ft/animal) & 48405 \\
\hline
\end{tabular}

Forrás (Source): Saját kalkuláció, 2020 (Authors' own calculation, 2020)

Megjegyzés (Note): ${ }^{1}$ Vállalkozás szintjén felmerülő menedzsmentköltségek (pl.: vállalkozás vezetőjének bére, utazási költségek, kamatok, tagdíjak, könyvelés) (Management costs incurred on farm level ((eg: manager's salary, travel expenses, interest, membership fees, accounting))

az összes költségen belül mintegy 45\%-ot, míg az anyag jellegü költségeken belül $80-85 \%$-ot tesz ki. A modellgazdaságban a tejelő tehenek takarmányozása alapvetően a silókukorica szilázson, szénaféléken és a gabona magvak felhasználásán alapul, így ezek mindenkori árszínvonala meghatározó a takarmányozási költségek alakulásában.

A gazdaság költségszerkezetét vizsgálva (6. táblázat), az anyag jellegü költségek a teljes termelési költségből, mintegy 66\%-ot tesznek ki, az egy állatra jutó anyag költség 863,2 ezer $\mathrm{Ft} /$ tehén. Ezen belül a takarmányköltségek részaránya 82,2\%-ot képvisel. A termelés közvetlen költsége meghaladja az 1,1 millió Ft-ot tehenenként, mely magasabb, mint az országos átlag, de ez egy ilyen intenzív termelési szinten termelő telepnél nem számít kiugróan magas értéknek. Az egy tehénre jutó munkaidő átlagosan 92,1 óra/tehén. 
KovÁCS, K. - VIDA, V. - MADAI, H. - SzÚCS, I.

6. TÁBLÁZAT

TABLE 6

A tejtermelés termelési költségének alakulása a modellezett, jó színvonalú üzemben (The Production Cost of Milk Production in a Good Quality Farm)

\begin{tabular}{|c|c|c|c|}
\hline Megnevezés (Description) & $\begin{array}{l}\text { Ágazati ösz- } \\
\text { szesen (ezer } \\
\text { Ft) (Total } \\
\text { Sectoral - in } \\
\text { thousand } \\
\text { HUF) }\end{array}$ & $\begin{array}{c}1 \text { tehénre jutó } \\
\text { költség (ezer Ft) } \\
\text { (Cost for } 1 \text { dairy } \\
\text { cow in thousand } \\
\text { HUF) }\end{array}$ & $\begin{array}{c}\text { Meg- } \\
\text { oszlás } \\
\text { (\%) } \\
\text { (Share) }\end{array}$ \\
\hline Anyag jellegű költség (Material cost) & 639019,6 & 863,2 & 66 \\
\hline Személyi jellegű költség (Labour cost) & 81026,8 & 109,4 & 8 \\
\hline Speciális tárgyi eszköz jellegű költség (Specific equipment cost) & 108652,9 & 146,8 & 11 \\
\hline $\begin{array}{l}\text { KÖZVETLEN KÖLTSÉGEK ÖSSZESEN (TOTAL DIRECT } \\
C O S T \text { ) }\end{array}$ & 828699,3 & 1119,4 & 85 \\
\hline Felosztott költség (gépi szolg.) (Splitted cost (machine service)) & 76285,3 & 103,0 & 8 \\
\hline ELŐÁLLÍTÁSI KÖLTSÉG (PRODUCTION COST) & 904984,6 & 1222,4 & 93 \\
\hline Általános költség (Overheads) & 66295,9 & 89,5 & 7 \\
\hline ÖSSZES KÖLTSÉG (Total Production cost) & 971280,6 & 1312,0 & 100 \\
\hline
\end{tabular}

Forrás (Source): Saját kalkuláció, 2020 (Authors' own calculation, 2020)

4.3. Hozamok, termelési érték, árbevétel és jövedelem - Yields, Production Value, Revenue and Income

A jó technológiával rendelkező közepes méretü modellüzem hozamait és termései értékeit mutatja a 7. táblázat. A főtermék hozama, mintegy 71\%-ban járul hozzá a termelési értékhez, az élőállat értékesítés összesen mintegy 10\%-ot képvisel, a szerves trágya, mint melléktermék értéke 6\%-ot, míg a különféle támogatások részaránya a termelési értékben mintegy $11 \%$ ot képvisel. A modell gazdaság jó termelési technológiával rendelkezik, az átlagos tehenenkénti éves tejhozam eléri a 11 ezer kilogrammot, melyek az aktuális árakon $100 \mathrm{Ft} / \mathrm{kg}$-os átlagáron tud értékesíteni.

A hozamok és a támogatások alakulása a modellezett üzemben

TABLE 7 (Yields and Subsidies in the Modelled Farm)

\begin{tabular}{|c|c|c|c|c|}
\hline Termék (Product) & $\begin{array}{c}\text { Fajlagos } \\
\text { hozam (kg/ } \\
\text { db) Specific } \\
\text { yield - kg/ } \\
\text { piece) }\end{array}$ & $\begin{array}{c}\text { Összes } \\
\text { hozam } \\
(t) \\
\text { (Total } \\
\text { yield) } \\
\text { (tons) }\end{array}$ & $\begin{array}{c}\text { Termelési } \\
\text { érték (ezer Ft) } \\
\text { (Production } \\
\text { value - } \\
\text { thousand } \\
\text { HUF) }\end{array}$ & $\begin{array}{c}\text { Meg- } \\
\text { oszlás } \\
(\%) \\
\text { (Share) }\end{array}$ \\
\hline Tej (Milk) & 11000,0 & 8143,7 & 814366,7 & 71 \\
\hline Hízómarha (Fattening cattle) & 511,1 & 131,9 & 79124,5 & 7 \\
\hline Növendék üsző (Adult heifer) & 509,8 & 12,2 & 6240,3 & 1 \\
\hline Trágya (Manure) & - & 24331,0 & 72993,0 & 6 \\
\hline Selejt tehén (Culled cow) & 549,3 & 74,7 & 24352,0 & 2 \\
\hline Itatásos borjú (Young cattle) & 59,5 & 7,5 & 4103,0 & o \\
\hline Tejkvóta támogatás (Milk quota support) & - & - & 48870,0 & 4 \\
\hline $\begin{array}{l}\text { Termeléshez kötött tejhasznú tehén (Dairy cow suport for } \\
\text { production) }\end{array}$ & - & - & 80605,3 & 7 \\
\hline $\begin{array}{l}\text { Termeléshez kötött hízottbika (Fattening bull support } \\
\text { (EU+national source) }\end{array}$ & - & - & 15725,6 & 1 \\
\hline
\end{tabular}

Forrás (Source): Saját kalkuláció, 2020 (Authors’own calculation, 202O) 
A tejtermelés árbevételének az egy tehénre jutó értéke meghaladja az 1,3 millió Ft-ot, melyhez jön még az uniós és állami támogatás, melynek egy része bázis időszak alapján számítódik, a másik része termelési szinthez kötött támogatás. Jelenlegi számításnál egy át- lagos bázisértéket vettünk alapul a támogatás kiszámításakor, mely a bázis időszak termelési szintjét tükrözi, illetve állat létszámát, ez egy átlagos üzemnél 5-15\%-kal is alatta marad a jelenlegi szintjének (8. táblázat).

8. TÁBLÁZAT

TABLE 8

A tejtermelés termelési értékének és jövedelmének alakulása a modellezett, jó színvonalú üzemben

(Production Value and Income of Milk Production in the Modeled Good Quality Farm)

\begin{tabular}{|c|c|c|}
\hline Megnevezés (Description) & $\begin{array}{l}\text { Ágazati összesen (ezer } \\
\text { Ft) (Total sectorial - } \\
\text { thousand HUF) }\end{array}$ & $\begin{array}{c}1 \text { tehénre jutó érték (ezer Ft/ } \\
\text { tehén) (For } 1 \text { dairy cow - } \\
\text { thousand HUF/dairy cow) }\end{array}$ \\
\hline Árbevétel (Sales revenue) & 980059,9 & 1323,8 \\
\hline Támogatások (Supports) & 145200,8 & 196,1 \\
\hline Belső felhasználás (tej) (Internal use (milk)) & 21119,5 & 28,5 \\
\hline $\begin{array}{l}\text { Termelési érték összesen (Total production } \\
\text { value) }\end{array}$ & 1146380,3 & 1548,5 \\
\hline Közvetlen termelési költség (Direct production cost) & 828699,3 & 1119,4 \\
\hline Fedezeti összeg (Coverage amount) & 317681,0 & 429,1 \\
\hline $\begin{array}{l}\text { Termelési költség összesen (Total Production } \\
\text { cost) }\end{array}$ & 971280,6 & 1312,0 \\
\hline Nettó jövedelem (Net income) & 175099,7 & 236,5 \\
\hline EBITDA & 299511,6 & 404,6 \\
\hline
\end{tabular}

Forrás (Source): Saját kalkuláció, 2020 (Authors'own calculation, 2020)

A tejtermelés fedezeti összege kissé meghaladja a 429 ezer Ft/tehén értéket és az általános költségeket is beleszámítva, a tehenenként realizált nettó jövedelem mintegy 236 ezer Ft/ tehén. A közel 300 millió Ft-os telepi és mintegy 404 ezer Ft/tehén EBITDA érték relatíve jó értéknek számít.

\subsection{Hatékonyság - Efficiency}

A legtöbb esetben a hatékonyságot kizárólag egyes tevékenységek mérhető, számszerüsíthető eredményeként tárgyalják, azonban a hatékonyságot a nemzetgazdaság, a társadalom, a régiók, a vállalatok és a vállalati egységek szempontjából is lehet vizsgálni különböző mutatókkal (NÁBRÁDI et al., 2009). A hatékonysági mutatók közül a hasonló tanulmányokban (SZŐLLŐSI és MOLNÁR, 2018; MARCZIN et al., 2020; SZÁNTÓ et al., 2020) a leggyakrabban használt mutatókat választottuk ki mi is az ágazat helyzetének vizsgálatára, úgymint a költségarányos jövedelmezőségi mutató, köz- vetlen költségarányos jövedelmezőségi mutató, (ár)bevétel arányos jövedelmezőségi mutató stb.

A vizsgált modellgazdaság legfóbb hatékonysági mutatója, a költség arányos jövedelmezőségi ráta, mely 18,8\%. Ettől kicsit jobb értéket mutat, ha csak a közvetlen költségek alapján számítjuk, így a közvetlenköltség-arányos jövedelmezőséget kapjuk meg, melynek értéke 34,7\%. Ez utóbbi a tejtermelő üzemeknél igen jónak mondható az elmúlt időszak gazdasági környezetét figyelembe véve. Fontos mutató még az egy munkaórára jutó nettó jövedelem, mely $2600 \mathrm{Ft} /$ óra a vizsgált tehenészetben, illetve a fajlagos, azaz az egy liter tej termelésére jutó takarmány költség, mely 64,5 Ft/liter. A modellkalkuláció alapján a bevételarányosjövedelmezőség a termelési érték alapján került kiszámításra és értéke 15,3\%. A jó termelési színvonalon termelő telep zöldmezős beruházási értéke mintegy 1,8 milliárd forintból valósulna meg, ennek alapján a ROI mutató értéke 11,7\%. A korábban bemutatott EBITDA 
KovÁcs, K. - VidA, V. - MADAI, H. - Szúcs, I.

mutató és a termelési érték alapján számított EBITDA margin mutatója 26,1\% (9. táblázat).

A tejtermelésnél jövedelmezőségének két fontos befolyásoló tényező a mindenkori tejértékesítési ár, mely a vizsgált gazdaság esetében átlagosan $100 \mathrm{Ft} / \mathrm{kg}$ volt, illetve az egy tehénre jutó tejhozam alakulása, mely egy jó színvonalon termelő gazdaság esetében átlagos 11000 $\mathrm{kg} /$ tehén volt. Ezen két tényező változása érzékenyen érinti az ágazati eredményt. Kereszttáblaelemzéssel vizsgálva megállapítható, hogy a 11 ezer kg-os átlagos tejhozam esetében a tej ár $5 \mathrm{Ft} / \mathrm{kg}$-es csökkenése mintegy 10,2\%-ban csökkenti az ágazati eredményt tehenenként (10. táblázat).

9. TÁBLÁZAT

TABLE 9

A tejtermelés hatékonysága a modellezett, jó színvonalú telepen (Efficiency of Milk Production on the Modelled, Good Quality Farm)

\begin{tabular}{lcc}
\hline \multicolumn{1}{c}{ Megnevezés (Description) } & $\begin{array}{c}\text { Mértékegység (Measuring } \\
\text { unit) }\end{array}$ & $\begin{array}{c}\text { Érték } \\
\text { (Value) }\end{array}$ \\
\hline $\begin{array}{l}\text { Élőmunka hatékonyság (telepi dolgozóra) (Living work efficiency (per } \\
\text { farm worker)) }\end{array}$ & $\begin{array}{c}\text { tehén/fó (cow/person) } \\
27,42\end{array}$ \\
\hline $\begin{array}{l}\text { Élömunka hatékonyság (telepi dolgozóra) (Living work efficiency (per } \\
\text { farm worker)) }\end{array}$ & $\begin{array}{c}\text { tonna tej/fö (tons of milk/ } \\
\text { person) }\end{array}$ & 301,61 \\
\hline Közvetlen önköltség (tej) (Direct unit cost (milk)) & Ft/kg & 75,10 \\
\hline Teljes önköltség (tej) (Total unit cost (milk)) & Ft/liter & 89,30 \\
\hline Közvetlenköltség-arányos jövedelmezóség (Direct cost rate of return) & $\%$ & 34,70 \\
\hline Költségarányos jövedelmezóségi ráta (Cost rate of return) & $\%$ & 18,80 \\
\hline Jövedelemszint (Income level) & $\%$ & 15,30 \\
\hline Költségszint (Cost level) & $\%$ & 84,70 \\
\hline ROS & $\%$ & 15,27 \\
\hline ROI & $\%$ & 11,67 \\
\hline EBITDA margin & & 26,13 \\
\hline
\end{tabular}

Forrás (Source): Saját kalkuláció, 2020 (Authors'own calculation, 2020)

10. TÁBLÁZAT

TABLE 10

Az egy tehénre jutó nettó jövedelem alakulása a tej értékesítési ára, illetve az egy tehénre jutó laktációs tejtermelés függvényében

(The Net Income Per Cow by the Selling Price of Milk and the Production of Lactating Milk Per Cow)

\begin{tabular}{|c|c|c|c|c|c|c|c|c|c|c|c|c|}
\hline \multirow{2}{*}{\multicolumn{2}{|c|}{$\begin{array}{c}\text { Nettó } \\
\text { jövedelem } \\
\text { (Ft/tehén) } \\
\text { (Net income } \\
\text { HUF/cow) }\end{array}$}} & \multicolumn{11}{|c|}{ Tej értékesítési ár (Ft/kg) (Milk sales price - HUF/kg) } \\
\hline & & 75 & 80 & 85 & 90 & 95 & 100 & 105 & 110 & 115 & 120 & 125 \\
\hline \multirow{11}{*}{ 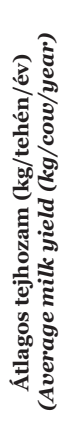 } & 6000 & -110542 & -80542 & -50542 & -20542 & 9458 & 39458 & $6945^{8}$ & 99458 & 129458 & 159458 & 189458 \\
\hline & 6500 & -73042 & -40542 & -8042 & 24458 & 56958 & 89458 & 121958 & 154458 & 186958 & 219458 & 251958 \\
\hline & 7000 & -35542 & -542 & 34458 & 69458 & 104458 & 139458 & 174458 & 209458 & 244458 & 279458 & 314458 \\
\hline & 7500 & 1958 & 39458 & 76958 & 114458 & 151958 & 189458 & 226958 & 264458 & 301958 & 339458 & 376958 \\
\hline & 8000 & 39458 & 79458 & 119458 & 159458 & 199458 & 239458 & 279458 & 319458 & 359458 & 399458 & 439458 \\
\hline & 8500 & 76958 & 119458 & 161958 & 204458 & 246958 & 289458 & 331958 & 374458 & 416958 & 459458 & 501958 \\
\hline & 9000 & 114458 & 159458 & 204458 & 249458 & 294458 & 339458 & $38445^{8}$ & 429458 & 474458 & 519458 & 564458 \\
\hline & 9500 & 151958 & 199458 & 246958 & 294458 & 341958 & 389458 & 436958 & 484458 & 531958 & 579458 & 626958 \\
\hline & 10000 & 189458 & 239458 & 289458 & 339458 & 389458 & 439458 & 489458 & 539458 & 589458 & 639458 & 689458 \\
\hline & 11000 & $26445^{8}$ & $31945^{8}$ & 374458 & 429458 & 484458 & 539458 & 594458 & 649458 & 704458 & 759458 & 814458 \\
\hline & 12000 & 339458 & 399458 & 459458 & 519458 & 579458 & $63945^{8}$ & 699458 & 759458 & 819458 & 879458 & 939458 \\
\hline
\end{tabular}

Forrás (Source): Saját kalkuláció, 2020 (Authors'own calculation, 202O) 
Ha a hozamok tekintetében vizsgáljuk a gazdaság érzékenységét, és 100 forintos kilogrammonként árat feltételezünk, akkor megállapítható, hogy ha a fajlagos telepi átlagos tejhozam 11 ezer kg/tehén szintjéról 10 ezer kg-ra csökken, akkor az ágazati eredmény egy tehénre vetítve is csökken 22,8\%-kal. A veszteséges tartomány a kereszttábla bal felső sarkában található, ami 6000-7000 kg-os tejtermelési színvonalat jelent és itt egy 5-10 forintos tej ár csökkenés, mely kb. 10\%-os csökkenést jelent a piacon, veszteségessé teszi a tejtermelést a gazdaságban. Ezért a termelők számára kiemelt fontosságú, hogy a tejtermelés átlagos szintje tehenenként meghaladja a $7500 \mathrm{~kg}$-os szintet, hogy biztosítva legyen a gazdasági fenntarthatóságuk (10. táblázat).

Az egy tehénre jutó nettó jövedelem alakulása a tej értékesítési ára, illetve az egy tehénre jutó takarmányköltség függvényében

(The Net Income Per Cow by the Selling Price of Milk and the Cost of Feed Per Cow)

\begin{tabular}{|c|c|c|c|c|c|c|c|c|c|c|c|c|}
\hline \multirow{2}{*}{\multicolumn{2}{|c|}{$\begin{array}{c}\text { Nettó } \\
\text { jövedelem } \\
\text { (Ft/tehén) } \\
\text { (Net income } \\
\text { HUF/cow) }\end{array}$}} & \multicolumn{11}{|c|}{ Tej értékesítési ár (Ft/kg) (Milk sales price - HUF/kg) } \\
\hline & & 75 & 80 & 85 & 90 & 95 & 100 & 105 & 110 & 115 & 120 & 125 \\
\hline \multirow{11}{*}{ 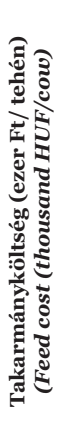 } & 200 & 218433 & 259328 & 300223 & 341118 & 382013 & 422908 & 463803 & 504698 & 545593 & 586488 & 627383 \\
\hline & 250 & 168433 & 209328 & 250223 & 291118 & 332013 & 372908 & 413803 & 454698 & 495593 & 536488 & 577383 \\
\hline & 300 & 118433 & 159328 & 200223 & 241118 & 282013 & 322908 & 363803 & 404698 & 445593 & 486488 & 527383 \\
\hline & 350 & 68433 & 109328 & 150223 & 191118 & 232013 & 272908 & 313803 & 354698 & 395593 & 436488 & 477383 \\
\hline & 400 & 18433 & 59328 & 100223 & 141118 & 182013 & 222908 & 263803 & 304698 & 345593 & 386488 & 427383 \\
\hline & 450 & -31567 & 9328 & 50223 & 91118 & 132013 & 172908 & 213803 & 254698 & 295593 & 336488 & 377383 \\
\hline & 500 & -81567 & -40672 & 223 & 41118 & 82013 & 122908 & 163803 & 204698 & 245593 & 286488 & 327383 \\
\hline & 550 & -131567 & -90672 & -49777 & -8882 & 32013 & 72908 & 113803 & 154698 & 195593 & 236488 & 277383 \\
\hline & 600 & -181567 & -140672 & -99777 & -58882 & -17987 & 22908 & 63803 & 104698 & 145593 & 186488 & 227383 \\
\hline & 650 & -231567 & -190672 & -149777 & -108882 & -67987 & -27092 & 13803 & 54698 & 95593 & 136488 & 177383 \\
\hline & 700 & -281567 & -240672 & -199777 & -158882 & -117987 & -77092 & -36197 & 4698 & 45593 & 86488 & 127383 \\
\hline
\end{tabular}

Forrás (Source): Saját kalkuláció, 2020 (Authors'own calculation, 2020)

A tejtermelő gazdaságokban a termelési költségen belül az anyagköltségek teszik ki a költségek legnagyobb hányadát, mely esetünkben $66 \%$ volt. Ezen belül a takarmányköltségek részaránya a legnagyobb tétel, mely a vizsgált gazdaságban az anyagköltségeken belül mintegy 76\%. Így természetesen a takarmányköltség változása is jelentősen hat az ágazati eredményre. A takarmányköltségek egy tehénre jutó értéke a modellgazdaságban 350-500 ezer Ft/tehén volt. A jelenlegi takarmányár 14\%-os növekedése (350 ezer Ft/tehénról 400 ezer Ft/ tehénre), mintegy 18,3\%-kal csökkentené az egy tehénre jutó ágazati eredményt. A jelenlegi tejértékesítési ár mellett, ha a takarmány ár fajlagosan 650 ezer Ft/tehén szintre emelkedik, veszteségessé válik a termelés. Természetesen ebben jelentős szerepet játszik az abraktakarmányok árának emelkedése, de kicsit ellensúlyozhatja ezt az emelkedő hatást, ha a telepnek magasabb részarányú a saját előállítású takarmánya, illetve jó a tömegtakarmánykészítés technológiája, mert ez kulcsfontosságú a takarmányköltségek csökkentése terén (11. táblázat).

A tejtermelő gazdaságok Magyarországon és az EU-ban is jelentősen függenek a támogatás nagyságától. A vizsgált modellgazdaság teljes termelési értékén belül ez a tétel 12\%-ot tett ki. Ezt nehéz általánosítani, mert többféle jogcímen érhető el az ágazatban, úgymint tejkvóta támogatás, termeléshez kötött tejhasznú tehén támogatás illetve termeléshez kötött hízott bika támogatás. A legtöbb támogatás kiinduló alapja egy történelmi bázis állatlétszám, vagy tejhozam, melyre termeléstől függetlenül jár a támogatás, illetve van egy termeléshez kötött része is. Ez minden tejtermelő gazda- 
ságnál más és más. Jelenleg egy átlagos értéket vettünk alapul a modellhez. Kereszttábla elemzéssel vizsgálhatjuk azt is, hogy milyen hatása van a támogatásoknak és az értékesítési árak változásának a fajlagos ágazati eredmény alakulására. Azt láthatjuk, hogy támogatások nélkül a 90-92 Ft/kg-os tej ár már veszteséget okozna a gazdaság számára. A mostani mintegy 150-200 ezer forint tehenenkénti támogatási szinten még a jól múködő gazdaságok is 75 Ft/ kg-os értékesítési áron érhetik el a veszteséges tartományt (12. táblázat).

Az egy tehénre jutó nettó jövedelem alakulása a tej értékesítési ára, illetve az egy tehénre jutó takarmányköltség függvényében

(The Net Income Per Cow by the Selling Price of Milk and the Cost of Feed Per Cow)

\begin{tabular}{|c|c|c|c|c|c|c|c|c|c|c|c|c|}
\hline \multirow{2}{*}{\multicolumn{2}{|c|}{$\begin{array}{c}\text { Nettó } \\
\text { jövedelem } \\
\text { (Ft/tehén) } \\
\text { (Net income } \\
\text { HUF/cow) }\end{array}$}} & \multicolumn{11}{|c|}{ Tej értékesítési ár (Ft/kg) (Milk sales price - HUF/kg) } \\
\hline & & 75 & 80 & 85 & 90 & 95 & 100 & 105 & 110 & 115 & 120 & 125 \\
\hline \multirow{11}{*}{ 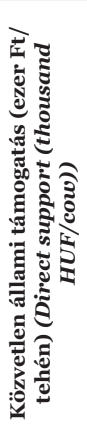 } & o & -129684 & -88789 & -47894 & -6999 & 33896 & 74791 & 115686 & 156581 & 197476 & 238371 & 279266 \\
\hline & 50 & -79684 & -38789 & 2106 & 43001 & 83896 & 124791 & 165686 & 206581 & 247476 & 288371 & 329266 \\
\hline & 100 & -29684 & 11211 & 52106 & 93001 & 133896 & 174791 & 215686 & 256581 & 297476 & 338371 & 379266 \\
\hline & 150 & 20316 & 61211 & 102106 & 143001 & 183896 & 224791 & 265686 & 306581 & 347476 & 388371 & 429266 \\
\hline & 200 & 70316 & 111211 & 152106 & 193001 & 233896 & 274791 & 315686 & 356581 & 397476 & 438371 & 479266 \\
\hline & 250 & 120316 & 161211 & 202106 & 243001 & 283896 & 324791 & 365686 & 406581 & 447476 & 488371 & 529266 \\
\hline & 300 & 170316 & 211211 & 252106 & 293001 & 333896 & 374791 & 415686 & 456581 & 497476 & 538371 & 579266 \\
\hline & 350 & 220316 & 261211 & 302106 & 343001 & 383896 & 424791 & 465686 & 506581 & 547476 & 588371 & 629266 \\
\hline & 400 & 270316 & 311211 & 352106 & 393001 & 433896 & 474791 & 515686 & $55^{6} 581$ & 597476 & 638371 & 679266 \\
\hline & 450 & 320316 & 361211 & 402106 & 443001 & 483896 & 524791 & 565686 & 606581 & 647476 & 688371 & 729266 \\
\hline & 500 & 370316 & 411211 & 452106 & 493001 & 533896 & 574791 & 615686 & 656581 & 697476 & 738371 & 779266 \\
\hline
\end{tabular}

Forrás (Source): Saját kalkuláció, 2020 (Authors'own calculation, 2020)

\subsection{Beruházásgazdaságosság - Investment Analysis}

A versenyképes tejtermelés elengedhetetlen feltétele a korszerü technológia, a genetikai alapokon, a jó minőségű takarmánybázison, a hatékony munkaszervezésen és kiváló üzemgazdasági szemléleten túlmenően. Az épületek és a fejéstechnológiai berendezések értéke igen különböző lehet, annak függvényében, hogy milyen automatizálási megoldásokat építünk be a rendszerbe, illetve az adott területen milyen minőségű és létszámú fizikai dolgozóállomány áll rendelkezésünkre. WARD (1990) a precíziós technológiai beruházások három előnyét említi: az emberi munka helyettesítő gépi teljesítménnyel; javítva a termelékenységet és az alkalmazottakat hatékonyság a feladatok el- végzésének új módszerein keresztül; innovatív és növeli a versenyképességet. Hazánkba jelenleg a telepautomatizálást, nem minden esetben a költséghatékonyág növelése indukálja, sok esetben a rendelkezésre álló munkaerő hiánya a fő kényszerítő erő az élőmunka gépimunkával való kiváltásának. A vizsgált modellüzem beruházási költségét (automatizált fejőházzal), zöldmezős beruházás esetén - több szakértői véleményt és becslést is figyelembe véve -, mintegy 1,8 milliárd Ft-ra lehet taksálni, egy 750-es tehénállományt tartó gazdaság esetében. Természetesen ez beruházási érték nagyban függ a beépített technológiától és az automatizálási megoldásoktól is, de a tervezett beruházás egy jó színvonalon termelő közepes gazdaságot feltételez. 
A beruházásgazdaságossági mutatók alakulása különböző támogatási intenzitás esetén (t=10 év, $\mathbf{r}=\mathbf{2}, 67 \%$ )

(Investment Analysis Indicators in Case of Different Subsidy Intensities $(t=10$ years, $r=2.67 \%)$

\begin{tabular}{lcccc}
\hline \multicolumn{1}{c}{ Megnevezés (Description) } & $\begin{array}{c}\text { NPV (ezer Ft) } \\
\text { (thousand HUF) }\end{array}$ & PI & IRR (\%) & $\begin{array}{c}\text { DPP (év, } \\
\text { year) }\end{array}$ \\
\hline Támogatás nélkül (Without support) & -99538 & 1,07 & 1,38 & 10,64 \\
\hline 30\% tám. int. (With 30\% support intensity) & 440462 & 1,52 & 10,36 & 7,53 \\
\hline 40\% tám. int. (With 40\% support intensity) & 620462 & 1,78 & 15,07 & 6,38 \\
\hline 50\% tám. int. (With 50\% support intensity) & 800462 & 2,13 & 21,56 & 5,27 \\
\hline 60\% tám. int. (With 60\% support intensity) & 980462 & 2,66 & 31,43 & 4,18 \\
\hline
\end{tabular}

Forrás (Source): Saját kalkuláció, 2020 (Authors'own calculation, 2020)

Megjegyzés (Note): $\mathrm{t}=10$ év (year); $\mathrm{r}=2,67 \%$

Ha megvizsgáljuk egy ilyen beruházás megtérülési mutatószámait, 10 éves idótartamra, 2,67\%-os alternatívaköltség, azaz kalkulatív kamatláb (10 éves futamidejü állampapírok referenciahozamának elmúlt három éves átlaga) mellett, többféle támogatási szintet feltételezve a következő táblázatban szereplő eredményeket kapjuk (13. táblázat).

Összességében elmondható, hogy visszanem-térítendő támogatás nélkül a modellezett, nemzetközi szinten is korszerűnek számító üzem 10 éven belül nem térül meg (a megtérülés a 11. évre tehető), mindössze 1,38\% belső megtérülési rátával jellemezhető. Ahogy modell gazdaság beruházási modell kalkulációjából látható, ahogyan növeljük a támogatás intenzitását, úgy rövidül a megtérülési idő. Egy 50\%-os beruházási támogatási intenzitási szintet feltételezve, a beruházás 6 éven belül megtérül, itt a beruházás IRR értéke 21,56\%, a nettó jelentértéke több mint 800 millió forint.

\section{IRODALOMJEGYZÉK - REFERENCES}

AKI: Élőállat és Hús. Agrárpiaci Jelentések. NAIK Agrárgazdasági Kutatóintézet, 2019. 22 (13) http://repo.aki.gov. $\mathrm{hu} / 3420 / 1 / 2019 \_13 \% 20$ Eloallat\%20 es\%2ohus.pdf (Letöltés dátuma: 2021.02.09.)
AKI PÁIR: Tej és tejtermékek. NAIK Agrárgazdasági Kutató Intézet, Piaci Árinformációs Rendszer. 2020. $23 \quad$ (7) http://repo.aki.gov. hu/3625/1/2020_07_tej.pdf (Letöltés dátuma: 2021.02.09.)

Béri, B.: Egyetemi előadás anyag. Debreceni Egyetem, 2015.

Bewley, J. M.: Precision Dairy Farming: Advanced Analysis Solutions for Future Profitability The First North American Conference on Precision Dairy Management, 2010 (January).

Holló, I. - Szabó, F.: Szarvasmarhatenyésztés, Kaposvári Egyetem, Pannon Egyetem, Digitális Tankönyvtár, 2011. https://regi.tankonyvtar.hu/hu/tartalom/ tamop425/oo59_szarvasmarha_ tenyesztes/cho1so3.html (Letöltés dátuma: 2021.02.09.)

Húth, B. - Zubor, T. - Tóth, T. - Holló, G.: A tejelő szarvasmarha tenyésztésének és tartásának új kihívásai az automatizált technológiai rendszerek tükrében. Állattenyésztés és Takarmányozás. 2019. 68 (3) 238-246.

IFCN: IFCN Dairy Report. 2018. https:// ifcndairy.org/ifcn-dairy-report-2018/ (Letöltés dátuma: 2021.02.09.) 
KSH: A hazai mezőgazdaság teljesítménye 2019-ben (Mezőgazdasági számlarendszer, 2019). 2020a. https://www.ksh.hu/docs/ hun/xftp/idoszaki/mgszlak/2019/index. html (Letöltés dátuma: 2021.02.09.)

KSH: Állatállomány, 2019. december 1., 2020b. http://www.ksh.hu/docs/hun/ xftp/stattukor/allat/2019/index.html (Letöltés dátuma: 2021.02.09.)

Čechura, L - Kroupová, Z. Z.: Technical Efficiency in the European Dairy Industry: Can We Observe Systematic Failures in the Efficiency of Input Use? Sustainability. 2021. 13 (4) 1830. DOI: https://doi. org/10.3390/su13041830 www.mdpi. com/journal/sustainability

Marczin, T. - Balogh, P. - Nagy, L.: Egy magyar sertéságazati integráció pénzügyi modellezése. Gazdálkodás. 2020. 64 (4) 265-273. DOI: https://doi.org/10.22004/ ag.econ.305194

Nábrádi, A. - Pető, K. - Balogh, V. Szabó, E. - Bartha, A. - Kovács, K.: Efficiency Indicators in Different Dimension. Applied Studies in Agribusiness and Commerce. 2009. 3 (12) 7-22. DOI: https://doi.org/10.19041/ APSTRACT/2009/1-2/1
Popovics, P. A. - Tóth, J.: Az ártranszmisszió és az árak aszimmetrikus hatásának vizsgálata Magyarország tejvertikumában. Közgazdasági Szemle. 2006. 53 (4) 349-365.

Szántó, L. - Szúcs, I. - Szőllősi, L.: Hízóalapanyag-előállításra specializálódott magyarországi sertéstelep létesítésének és üzemeltetésének költségjövedelem és megtérülési viszonyai. Gazdálkodás. 2020. 64 (6) 484-496. DOI: https://doi.org/10.22004/ ag.econ.308450

Szőllősi, L. - Molnár, Sz.: Az étkezési tojástermelés gazdasági helyzete Magyarországon. Animal Welfare, Etológia és Tartástechnológia. 2018. 14 (1). 53-62.

Ward, J. M.: A Portfolio Approach to Evaluating Information Systems Investments and Setting Priorities. Journal of Information Technology. 1990. 5 (4) 222-231. DOI: https://doi. org/10.1177/026839629000500407 